\title{
GROWTH AND YIELD OF WHEAT VARIETIES UNDER RAISED BED SYSTEM
}

\author{
M. I. Hossain 1 , M. R. I. Mondal2 ${ }^{2}$, N. C. D. Barma ${ }^{3}$, M. A. Hakim4 and M. J. Islam \\ ${ }^{1}$ Senior Scientific Officer, ${ }^{5}$ Scientific Officer, Regional Wheat Research Centre, BARI, Rajshahi \\ ${ }^{2}$ Director General, Bangladesh Agricultural Research Institute, Joydebpur, Gazipur \\ ${ }^{3}$ Chief Scientific Officer, ${ }^{4}$ Senior Scientific Officer, Wheat Research Centre, Gazipur \& Dinajpur \\ Corresponding author: iliasrwrc@gmail.com
}

Key words: Growth, yield, wheat varieties, raised bed system

\begin{abstract}
A two-year experiment was conducted during Rabi season of 2012-13 and 2013-14 at the Regional Wheat Research Centre (RWRC), Bangladesh Agricultural Research Institute, Rajshahi. Recently released six varieties like Shatabdi, Bijoy, Prodip, BARI Gom 25, BARI Gom 26 and BARI Gom 27 were evaluated under raised bed system in randomized complete block design with three replications. The varieties were evaluated for yield, and yield components with some phenological and physiological parameters. The effects of raised bed system over two years were significant for all the parameters. The highest mean yield over tillage method (among the tested varieties) was produced by varieties BARI Gom 27 and Shatabdi followed by BARI Gom 26 and Bijoy varieties. These varieties produced satisfactory yields in raised bed methods. The lowest yielder varieties were Prodip and BARI Gom 25. Considering the overall growth, yield and other characters of three varieties like BARI Gom 27, Shatabdi and Bijoy have been provisionally selected at Rajshahi region as well as in wheat growing areas in Bangladesh.
\end{abstract}

\section{Introduction}

The demand for food production in Bangladesh is increasing day by day to feed the increasing population in the context of decreasing crop land due to construct of road, housing and other infrastructure. So, now it is the time demand to screen out suitable variety of cereal and other major crops and technology to meet the food demand. Most of the cereal, pulse and other crops have traditionally been planted after three ploughing followed by laddering which is slow, laborious, time consuming and also costly (Singh, 2003). The farmers are facing trouble to carry out agricultural operation due to labor shortage especially in the pick period. Tillage practices contribute greatly to the labor cost in any crop production system resulting in lower economic returns (Limon et al., 2006). Farmers in Indo-Gangetic Plains (IGP) of India are yet to grow maize under a double no-till system either on the flat or raised beds, although these are common practices in many western countries (Gupta et al., 2002). Reduced or conservation tillage is gaining more attention in recent years with increasing concerns about natural resource degradation. Intensive tillage systems result in increased soil compaction and decreased soil organic matter (Singh et al., 2005) and biodiversity (RWC-CIMMYT, 2003). Sub-soil compaction due to repeated tillage leads to reduced water and nutrient use efficiency (Aggarwal and Goswami, 2003).

Conservation tillage practices, such as zero and minimum tillage, may be introduced to offset the production cost and other constraints associated with environment and socio-economic conditions. Raised bed planting of maize helps achieve good plant establishment, increases input efficiency, increases yields, and opens up avenues for a double no-till system (Witt et al., 2000). 
62

Hossain et al.

The experiment was therefore undertaken to select the suitable varieties under raised bed system in drought prone area.

\section{Materials and Methods}

The trial was conducted with recently released six wheat varieties at the Regional Wheat Research Centre, BARI, Rajshahi in 2012-13 and 2013-14. The experiment was laid out in randomized complete block design with three replications. Seeds were sown by bed planter with 25 meter long x 2.4 m wide with 8 rows for six varieties namely Shatabdi, Prodip, Bijoy, BARI Gom 25, 26 and 27. Wheat Research Centre recommended management practices were followed to raise the crop with irrigation and other practices. Data were recorded on different agronomic parameters as well as phenological and physiological characteristics. At maturity, four rows with $2 \mathrm{~m}$ long plot size were harvested to estimate grain yield expressed as ton per hectare. The collected data were analyzed with Crop Stat Model and means were compared by MSTAT C model (Gomez and Gomez, 1984).

\section{Results and Discussion}

\section{Growth parameters}

Phenological data of six varieties under raised bed systems are presented in Table 1. Results revealed that Shatabdi and BARI Gom 27 were 2-3 days delayed over other varieties under raised bed systems. Days to heading, anthesis and physiological maturity were 3-4 days earlier in Prodip, BARI Gom 25 and BARI Gom 26 varieties under raised bed system over Shatabdi, Bijoy and BARI Gom 27 varieties. Finally raised bed systems significantly influenced the crop growth duration and as results Shatabdi, Bijoy and BARI Gom 27 varieties were longer crop duration (111-113 days) compared to Prodip, BARI Gom 25 and BARI Gom 26 (105-107 days). Among the six varieties, Shatabdi took maximum time of booting( 65 days), heading (74 days) and anthesis (79 days) followed by BARI Gom 27 and Bijoy and these varieties needed maximum time for maturity (113 days). Maximum booting time was also found from Shatabdi variety by Talukder et al. (2004). The reasons might be due to Shatabdi, Bijoy and BARI Gom 27 were highly sensitive under raised bed systems with get more border effect.

Table 1. Growth parameters of wheat varieties under raised bed systems

\begin{tabular}{l|c|c|c|c}
\hline Varieties & $\begin{array}{c}\text { Days to } \\
\text { booting }\end{array}$ & $\begin{array}{c}\text { Days to } \\
\text { heading }\end{array}$ & Days to anthesis & $\begin{array}{c}\text { Days to physiological } \\
\text { maturity }\end{array}$ \\
\hline Shatabdi & 65 & 74 & 79 & 113 \\
Bijoy & 64 & 72 & 77 & 111 \\
Prodip & 63 & 73 & 76 & 105 \\
BARI Gom 25 & 63 & 72 & 76 & 106 \\
BARI Gom 26 & 63 & 74 & 76 & 107 \\
BARI Gom 27 & 65 & 75 & 79 & 112 \\
\hline LSD $(0.05)$ & 1.17 & 1.74 & 1.62 & 1.13 \\
CV (\%) & 1.1 & 1.3 & 1.1 & 0.8 \\
\hline
\end{tabular}

Total dry matter increase $(p=.054)$ with increased the duration up to grain filling stage among all the varieties under raised bed systems and then slowly decreased (Fig. 1). Maximum dry matter production was higher in Shatabdi, Bijoy and BARI Gom 27 varieties due to its growth duration and gets more border effect and minimum in BARI Gom 25 and Prodip varieties due to its leaf senescence and mutual shading. Govaerts et al. (2006) found maximum dry matter in grain filling 
stage from mutual shading genotypes under raised bed systems. Leaf area index increase $(p=0.62)$ with increased the duration up to booting stage and there after decreased up to late grain filling stage. Maximum leaf area index was found from BARI Gom 27, Shatabdi and Bijoy varieties due to its longer duration and leaf senescence and minimum was Prodip and BARI Gom 25 and 26 varieties (Fig. 2). Hobbs and Gupta (2000) found maximum leaf area index in longer duration varieties from bed planting system.

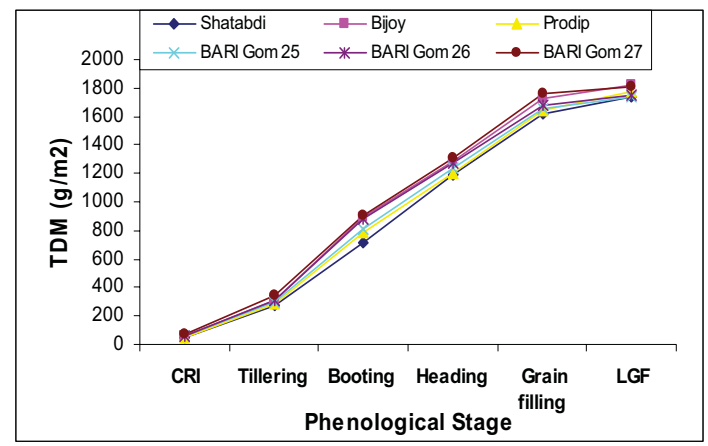

Fig. 1. TDM on varieties under RB systems.

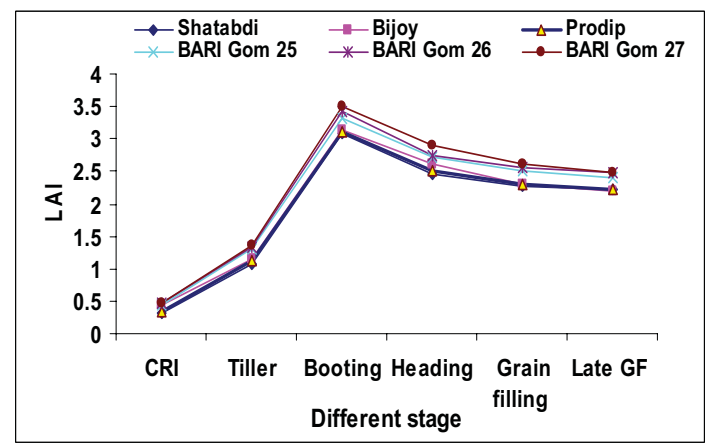

Fig. 2. LAI on varieties under RB system

The pattern of crop growth rate showed the similar trend in all the varieties under raised bed systems (Fig. 3). The crop growth rate ( $\mathrm{p}=0.32)$ significantly influenced by the phonological stage of wheat varieties under raised bed systems. The crop growth rate gradually increased up to booting to heading stage after sowing in all the varieties and it declined from heading to maturity. Kataki (2001) found maximum crop growth rate in booting to heading stage and lower in physiological stage from bed planting system. Generally at later growth stage, a declined CGR caused by mutual shading and leaf senescence reduces the photosynthetic efficiency and ultimately reduces the dry matter accumulation rate of a crop. Lauren et al. (2006) found minimum crop growth rate in physiological maturity stage under raised bed systems. Maximum crop growth rate was found from booting to heading stage and it was up down tendency on this stage after heading stage it was then decreasing up to late grain filling stage. Similar findings were also got by Talukder et al. (2002). The highest crop growth rate was found from BARI Gom 27, Shatabdi and Bijoy varieties and lowest was BARI Gom 25 and Prodip varieties. Ground coverage increase with increased up to booting stage and then decreasing up to late grain filling stage. Maximum ground coverage was also found from BARI Gom 26, BARI Gom 27 and Bijoy varieties and minimum was Prodip and BARI Gom 25 varieties( Fig. 4). Quayyum et al. (2002) found a maximum ground coverage from Bijoy variety over Prodip variety.

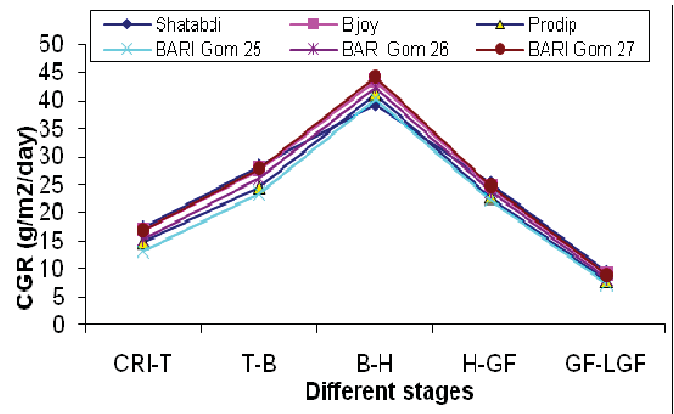

Fig. 3. CGR on wheat varieties under RB systems

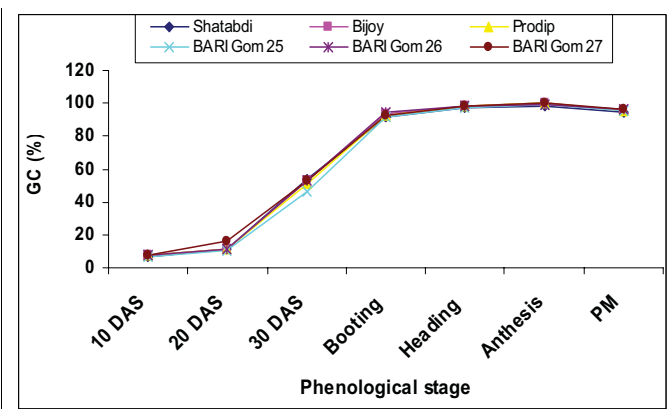

Fig. 4. GC (\%) on varieties under RB systems 
Hossain et al.

\section{Grain yield and yield components}

Grain yield is the cumulative effect of spike $\mathrm{m}^{-2}$, grains spike $e^{-1}$ and 1000 grain weight. Average two years yield and yield components data were shown in Table 2. Raised bed significantly influenced on grain yield and yield attributes under different wheat genotypes from two years data. The maximum grain yield was found $\left(4.71 \mathrm{t} \mathrm{ha}^{-1}\right)$ from BARI Gom 27 varieties and it was at par with BARI Gom $26\left(4.57 \mathrm{t} \mathrm{ha}^{-1}\right)$, Shatabdi $\left(4.53 \mathrm{t} \mathrm{ha}^{-1}\right)$ and Bijoy $\left(4.65 \mathrm{t} \mathrm{ha}^{-1}\right)$ variety. Grain yield was higher due to higher yield attributes, growth parameters and more tillering and border effect. Talukder et al. (2004) found more yield from Shatabdi variety under raised bed system. Other varieties produced fewer yields due to lower yield components and growth parameter. The minimum yield $\left(4.02 \mathrm{t} \mathrm{ha}^{-1}\right)$ was found from Prodip variety due to lower yield components and less tillering. Minimum grain yield was also found by Talukder et al. (2002) from prodip variety under bed planting system. Yield components were significantly influenced among the varieties under raised bed system. Maximum spike $\mathrm{m}^{-2}$ (397) was found from BARI Gom 27 variety followed by Bijoy (359) and Shatabdi (353) varieties. Maximum spike length $(10.6 \mathrm{~cm}$ ), spikelet spike $e^{-1}$ (20.3) and grains spike-1 (47.3) found from BARI Gom 27 variety followed by Shatabdi and Bijoy varieties. Talukder et al. (2004) found more spike length, spikelet spike-1 and grains spike $e^{-1}$ from Shatabdi and Bijoy varieties. Minimum spike (319), spike length (9.1) and grains spike $e^{-1}$ (44) obtained from prodip variety. Talukder et al. (2004) found similar findings from their experiments under raised bed system.

Table 2. Effect of recently released wheat varieties on yield \& yield attributes under raised bed system

\begin{tabular}{l|c|c|c|c|c|c}
\hline Varieties & $\begin{array}{c}\text { Spike } \\
\mathrm{m}^{-2}\end{array}$ & $\begin{array}{c}\text { Spike length } \\
(\mathrm{cm})\end{array}$ & $\begin{array}{c}\text { Spikelet } \\
\text { spike }^{-1}\end{array}$ & $\begin{array}{c}\text { Grains } \\
\text { spike } e^{-1}\end{array}$ & $\begin{array}{c}\text { TGW } \\
(\mathrm{g})\end{array}$ & $\begin{array}{c}\text { Av. 2 years } \\
\text { yield }\left(\mathrm{t} \mathrm{ha} \mathrm{a}^{-1}\right)\end{array}$ \\
\hline Shatabdi & 353 & 9.3 & 19.8 & 44.3 & 46.3 & 4.53 \\
Bijoy & 359 & 10.3 & 19.7 & 46.6 & 46.0 & 4.65 \\
Prodip & 319 & 9.1 & 18.3 & 44.6 & 47.6 & 4.02 \\
BARI Gom 25 & 335 & 10.0 & 18.6 & 44.0 & 46.3 & 4.17 \\
BARI Gom 26 & 322 & 10.3 & 18.9 & 44.3 & 50.3 & 4.57 \\
BARI Gom 27 & 397 & 10.6 & 20.3 & 47.3 & 45.6 & 4.71 \\
\hline LSD $(0.05)$ & 72.96 & 2.65 & 3.44 & 8.00 & 2.22 & 0.51 \\
CV (\%) & 11.5 & 14.7 & 10.2 & 9.7 & 9.7 & 7.2 \\
\hline
\end{tabular}

\section{Conclusion}

Based on the overall performance of both phenological and yield and yield attributes on six wheat varieties, it was concluded that Shatabdi, Bijoy, BARI Gom 26 and BARI Gom27 performed the best under raised bed condition. On the other hand, Prodip and BARI Gom 25 were the least performer under raised bed system.

\section{Acknowledgement}

We are very pleased to acknowledge International Maize and Wheat Improvement Centre (CIMMYT) Bangladesh for their cordial cooperation and financial assistance. 


\section{References}

Aggarwal, P. K. and B. Goswami. 2003. Bed planting system for increasing nutrients and water use efficiency of wheat grown on Inceptisol (Typic Ustochrept). Indian J. Agril. Sci.73 (8): 422 25.

Gomez, K. A. and A. A. Gomez. 1984. Statistical Procedures for Agricultural Research (second edition). John Wiley \& Sons, Inc., IRRI, Philippines, 680p.

Govaerts, B., K. D. Sayre and J. Deckers. 2006. Towards minimum data sets for soil quality assessment. The case of zero-tillage wheat/maize rotations in the highland of Mexico. Soil Tillage Res 87: 163-174.

Gupta, R. K., R. K. Naresh, P. R. Hobbs and J. K. Ladha. 2002. Adopting Conservation Agriculture in Rice-Wheat Systems of the Indo-Gangetic Plains- New Opportunities for Saving on Water. Paper presented at the "Water Wise Rice Production Workshop", 5- 10 April 2002, IRRI, Philippines.

Hobbs, P. R and R. K. Gupta. 2000. 'Soil and Crop Management Practices for Enhanced Productivity of the Rice-Wheat Cropping System in the Sichuan Province of China'. Rice-Wheat Consortium Paper Series 9. (RWC, New Delhi, India).

Kataki, P. K. 2001. The rice-wheat cropping system in South: Trends, Constraints and ProductivityA Prologue, J. Crop Prod. 3: 1-26.

Lauren, J. G., J. M. Duxbury, M. I. Hossain, G. Sah, A. S. M. H. M. Talukder and C. A. Meisner. 2006. Permanent raised bed cultivation improves nitrogen and water use in rice-wheat cropping systems of South Asia. $18^{\text {th }}$ World Science Congress, USA.

Limon, O. A., K. D. Sayre and C. A. Francis. 2006. Wheat and maize yields in response to straw management and nitrogen under a bed planting system. Agron. J. 92: 295-302.

Quayyum, M. A., J. Timsina, M. A. H. S. Jahan, R. A. Begum and D. J. Connor. 2002. Grain yield and system productivity for wheat-mungbean-rice and wheat-maize rice sequences in northern Bangladesh. Thai J. Agric. Sci. 35(1): 51-62.

RWC-CIMMYT. 2003. Addressing Resource Conservation Issues in Rice-Wheat Systems of South Asia: A Resource Book. RWC-CIMMYT, New Delhi, India.

Singh, Y. 2003. Crop Residue management in rice-wheat system. 2003. In: Addressing Resource Conservation Issues in Rice-Wheat Consortium for the Indo-Gangetic Plains. CIMMYT, New Delhi, India, p.153.

Singh, Y., B. Singh and J. Timsina. 2005. Crop residue management for nutrient cycling and improving soil productivity in rice-based cropping systems in the tropics. Adv. Agron. 85: 269-407.

Talukder, A. S. M. H. M., C. A. Meisner, M. J. Kabir, A. B. S. Hossain and M. Harun-ur-Rashid. 2004. Productivity of multi-crops sown on permanent raised beds in the tropics. In: New Direction for a Diverse Planet: Handbook and Abstracts for the $4^{\text {th }}$ International Crop Science Congress, Brisbane, Australia, 26 September -01 October 2004, p.173.

Talukder, A. S. M. H. M., M. A. Sufian and C. A. Meisner. 2002. Rice, wheat and mungbean yields in response to $\mathrm{N}$ levels and management under a bed planting system. In: Proceedings published in the $17^{\text {th }}$ World Congress of Soil Science, Bangkok, Thailand,v.1, Symposium no. 11, p.351. 
Hossain et al.

Witt, C., K. G. Cassman, D. C. Olk, U. Biker, S. P. Liboon, M. I. Samson and J. C. G. Ottow. 2000. Crop rotation and residue management effects on carbon sequestration, nitrogen cycling and productivity of irrigated rice systems. Plant Soil, 225: 263-278. 